\title{
Impact of Short-term Temporal Changes in Volcanic Ash Fall on Rainfall Threshold for Debris Flow Occurrence in Sakurajima, Japan
}

\author{
Hiroshi KISA $^{1}$, Takao YAMAKOSHI ${ }^{2}$, and Tadanori ISHIZUKA ${ }^{3}$ \\ ${ }^{1}$ Nippon Koei Co., Ltd (2, Kojimachi 4-chome, Chiyoda-ku, Tokyo 1020083, Japan), previously at the Public Works Research \\ Institute \\ E-mail: a6460@n-koei.co.jp \\ 2 Ministry of Land, Infrastructure, Transport and Tourism (1-3, Kasumigaseki 2-chome, Chiyoda-ku, Tokyo 1008918, Japan), \\ previously at the Public Works Research Institute \\ 3 Public Works Research Institute (1-6, Minamihara, Tsukuba, Ibaraki 3058516, Japan)
}

\begin{abstract}
Owing to the large quantities of volcanic ash that falls continuously on basins, it is generally known that debris flows can be easily triggered by even a small rainfall in such circumstances. The process of occurrence of debris flow is explained that the infiltration capacities of slopes are reduced because of the accumulation of ash, and therefore, rainfall events induce large quantities of surface runoff and subsequent increase in erosion. The authors established the observation slope at Sakurajima Volcano, one of the most active volcanos in Japan. Surface runoff was observed on the bare slope on which volcanic ash accumulates continuously by eruptions. The purpose of observation is better understanding the relationship between the amount of ash fall and the rainfall threshold for debris flow occurrence. The rainfall conditions necessary for the occurrence of surface runoff were investigated over an observation period that included periods of relatively high ash fall rates and periods with relatively low ash fall rates. Results reveal that there is no evident difference in rainfall intensity that causes surface runoff or in the apparent infiltration capacity of the slope in the case of short-term temporal changes in volcanic ash fall. It was also revealed that if a no-rain period lasts for a long time, the amount of rainfall loss from the onset of rains to the occurrence of surface runoff will increase to some extent.
\end{abstract}

Key words: Sakurajima volcano, volcanic ash fall, debris flow, rainfall threshold, surface runoff

\section{INTRODUCTION}

\subsection{The Background of the relationship between volcanic ash fall deposit and debris flow occurrence}

It has generally been known that rainfall causes debris flow frequently in basin where ash fall created by volcanic eruptions deposit thickly on the slope [e.g. Ikeya, 1993]. The process of occurrence of debris flow is explained by that the infiltration capacities of slopes are reduced because of the accumulation of ash, and therefore, rainfalls induce large quantities of surface runoff and subsequent increase in erosion [Collins et al., 1986]. After volcanic eruption settles down or ceases, the period in which debris flows are easily triggered still continues for several years [e.g. Ikeya, 1993]. It is considered, however, that the likelihood of debris flow occurrences gradually lowers with the passage of time even though a large amount of volcanic ash deposit remains on the slopes of the watershed.

There seem to be several reasons why debris flow occurrences gradually lower with the passage of time. For example, it is considered to be possible that the sediment discharge and debris flow from the volcanically disturbed watersheds decreases without increase in the infiltration capacity of the volcanic ash deposit in case that the original permeable under-layer was exposed by the gully formation [Yamakoshi et al, 2002]. It is also considered that the recovery of vegetation may lead to increased infiltration capacity of the slope of the pyroclastic material and to decreased sediment discharge and debris flow occurrences [Nishida et al., 1998]. 
On the other hand, in case the volcanic eruptions continues, owing to the large quantities of new volcanic ash that falls continuously on basins, the infiltration capacities of slopes remain low because of the accumulation of ash [Jitousono et al., 1989]. Therefore, the rainfall threshold of debris flow occurrences can remain low in such circumstances [Jitousono et al., 1991]. In addition, it is assumed that rainfall threshold of debris flow occurrence may vary in short term because of new ash supply by the eruptions and also by the erosions in case of rainfalls. Therefore, the authors decided to focus on the topic of the impact of short-term temporal changes in volcanic ash fall on rainfall threshold for debris flow occurrence in this report.

\subsection{About Sakurajima volcano and the purpose of this observation}

Sakurajima is a volcanic island located in the southern part of Kyusyu which is southernmost of the four main islands of Japan (Figure 1). In 1955, the Minamidake crater erupted, and there have been continuous eruptions at the crater since then, with alternating periods of high activity and relatively low activity. Eruptive activity at the Showa crater, located to the east of the Minamidake crater, has occurred since 2006. According to Japan Meteorological Agency, 996 explosive eruptions were observed in 2011, which is the highest number in the history of observation. The Ohsumi Construction Work Office, Kyushu Regional Construction Bureau, Ministry of Construction showed that in basins where ash has continuously fallen by volcanic eruptions, even rainfall events with low cumulative rainfall or rainfall intensity are prone to cause the occurrence of debris flow [The Ohsumi Construction Work Office, Kyushu Regional Construction Bureau, Ministry of Construction, 1988]. The previous work explained that the infiltration capacity of slopes considerably reduced because of the accumulation of ash, and therefore rainfall events induced surface runoff in large quantities and a subsequent increase in erosion [Jitousono et al., 1991]. The previous work also reported the amount of surface runoff on forest slopes on the northern side of Sakurajima Volcano, comparing the amount of surface runoff during a period of high ash fall rate in 1985 with that of a period of relatively low ash fall rate in 1987 . They reported that in the period of high ash fall rate, there was a rise in the surface runoff rate, and even light rainfall events caused surface runoff. The other work also reported about the surface runoff on bare slopes where pyroclastic materials accumulate [Nishida et al., 1998]. However, there is no report of

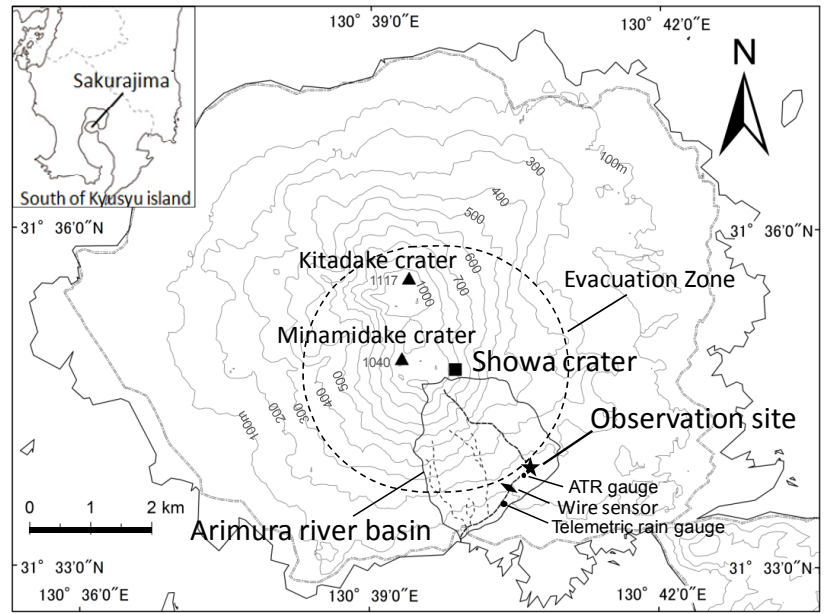

Fig. 1 The location of observation site

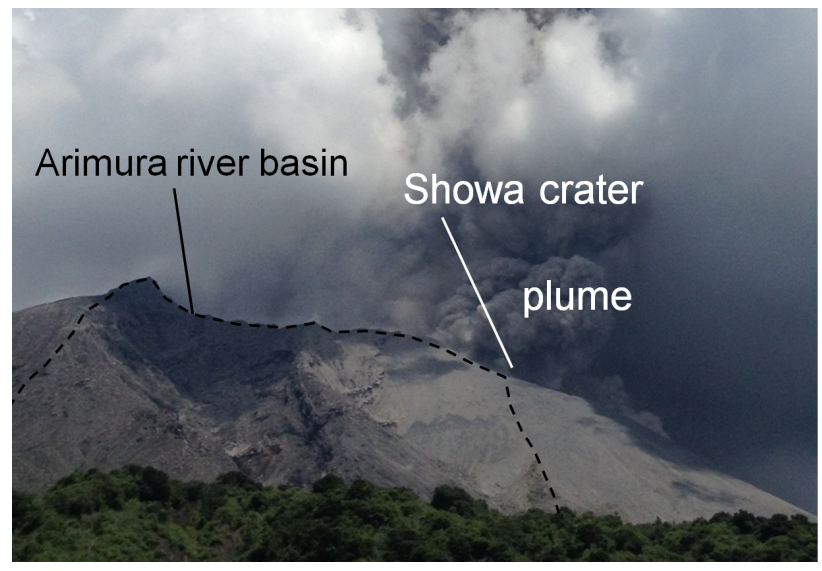

Fig. 2 An Eruption of Showa crater and Southeast flank of

Sakurajima

observations of the surface runoff on bare slopes on which volcanic ash is currently falling due to volcanic eruptions. Therefore, the influence of ash fall and erosion on the rainfall conditions contributing to surface runoff remains unclear.

In this study, observation equipment was installed on a slope of southeastern flank of Sakurajima on which volcanic ash is accumulating. The amount of surface runoff from the slope has been observed since December 2011, in order to reveal the relationship between the short-term ash fall and the rainfall threshold for the occurrence of debris flow through revealing the relationship between short-term ash fall and the surface runoff characteristics. This report relates observation data of the amount of surface runoff from the slope, and discusses the relationships between ash fall, rainfall, surface runoff, and debris flow.

\section{OBSERVATION SITE AND METHOD}

\subsection{Observation site}

Observations were conducted in the Arimura 
River basin located in the southeast of Sakurajima Volcano (Figures 1\&2). The basin area is $3.88 \mathrm{~km}^{2}$. The area within a 2-km radius from the Minamidake and the Showa crater is designated as the Evacuation Zone based on the Basic Act on Disaster Control Measures; and therefore, an observation slope was set-up outside of this area in the Arimura River basin, $2 \mathrm{~km}$ southeast of the Showa crater. The observation slope is set on the Showa lava and volcanic ash accumulated on the slope. The catchment area of the observation slope is measured approximately $1.8 \mathrm{~m}^{2}$, with a slope angle of about $12^{\circ}$. A preliminary observation of the soil profile of the observation slope revealed that volcanic ash had filled the porosity of blocks of auto-brecciated lava. The area paved by rock blocks is $0.4 \mathrm{~m}^{2}$ of the catchment area. With the exception of the pavement of the rock blocks of lava, the thickness of the volcanic ash layer of the slope surface measured to be more than $10 \mathrm{~cm}$.

\subsection{Observation system and principles of measurement}

It is necessary to make the process of surface runoff and erosion on slopes as the elementary process of occurrence of debris flow apparent. In addition, it is also need to be clarifying about how the historical process of erosion influences the surface runoff and erosions after several rainfall events, although the influence of the historical process of erosion is not mentioned in this paper. Therefore, the observation system must be established to enable us to measure the volume of the surface runoff and sediment erosion separately, continuously and automatically, in each surface runoff occurrence. In addition, to assume apparent infiltration capacity of the slope based on an analysis in chapter 5.3 , it is necessary to measure only water volume of the surface runoff not including sediment volume.

Figure 3 shows a schematic diagram of the observation system. Figure 4 shows the observation slope and the observation equipment. A container was placed on the lower side of the slope to catch water and sediment discharge. Its internal diameter is $56.7 \mathrm{~cm}$ and horizontal cross-sectional area is $2524.5 \mathrm{~cm}^{2}$. When surface runoff occurred on the slope during rainfall, water and sediment flowed into the container through a collecting gutter and pipe. The water level in the container was measured using a water gauge. The measurement error is \pm 1 $\mathrm{mm}$. Hydrographs of surface runoff (total volume of water and sediment) flowing into the container was recorded as increase in the water level in the container. The container was supported by three

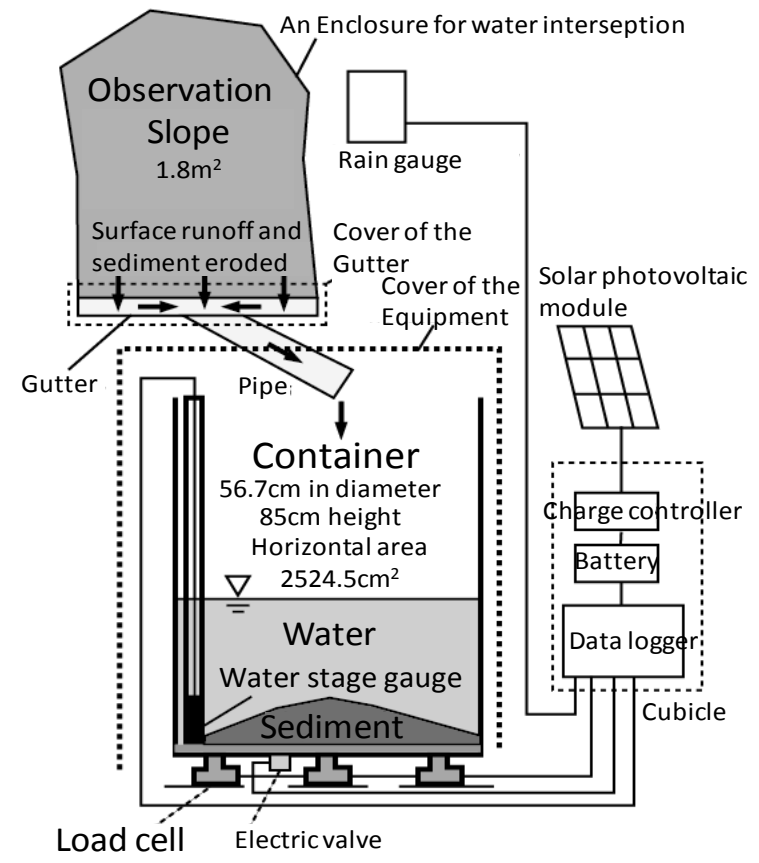

Fig. 3 The system of measurement

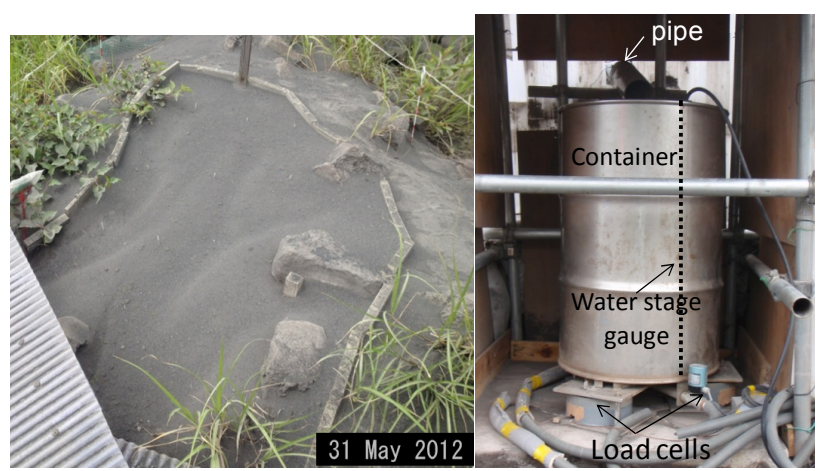

Fig. 4 The observation slope and the equipment

load cells, which measured the total weight of the water and sediment in the container. The water level and the total weight were recorded by a data logger at intervals of 10 minutes. Substituting the water level, total weight, and assumed grain density of sediment flowing into the container into Equation (1), the volume of sediment and water in the container can be estimated separately:

$$
\begin{aligned}
& W_{\mathrm{s}}=\left(W-S \cdot D \cdot \rho_{w}\right) /\left(1-\rho_{w} / \rho_{\mathrm{s}}\right) \\
& W_{\mathrm{w}}=W-W_{S}
\end{aligned}
$$

where $W_{s}$ is the weight of sediment in the container (g), $W$ is the total weight of water and sediment in the container $(\mathrm{g}), W_{w}$ is the weight of water in the container $(\mathrm{g}), S$ is the effective sectional area of the container $\left(\mathrm{cm}^{2},=2524.5\right), D$ is the water level $(\mathrm{cm})$, $\rho_{w}$ is the density of water $\left(\mathrm{g} / \mathrm{cm}^{3},=1.00\right)$, and $\rho_{s}$ is 


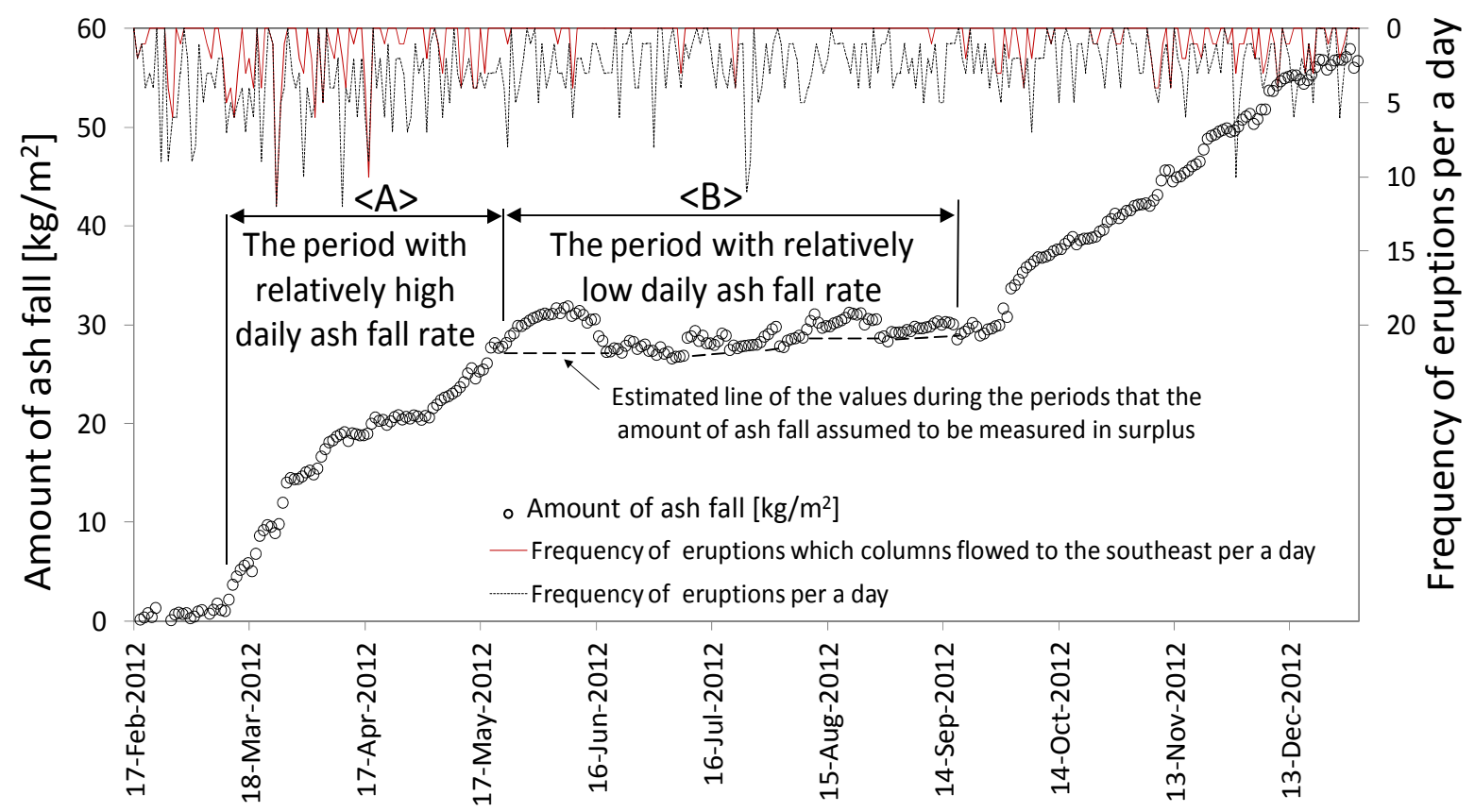

Fig. 5 The number of eruptions* and the ash fall amount monitored by the ATR gauge**

* source from Japan Meteorological Agency, ** source from Ohsumi Office of the River and National Highways, Kyushu

Regional Development Bureau, Ministry of Land, Infrastructure, Transport and Tourism

the grain density of sediment yield $\left(\mathrm{g} / \mathrm{cm}^{3}\right) \cdot \rho_{s}$ is taken as $2.703 \mathrm{~g} / \mathrm{cm}^{3}$ which is the density of volcanic ash which had accumulated near the observation slope prior to installation of the observation slope. The Equation (1) holds in case the water level is higher than the highest level of the surface of sediment. If the part of the sediment is higher than the surface of the water, $W_{s}$ will be measured as surplus. So, the water level should be kept higher than the highest level of the surface of sediment.

The total sediment flowing into the container during the observation period was collected almost bi-monthly, and the oven-dried weight of the sediment was measured. It should be noted that because two of the three load cells showed measurement anomalies throughout the observation period due to the malfunction by unexpected inundation of them, the total weight of water and sediment in the container, $W$, could not be measured so accurately as we expected. However, values obtained by multiplying factors by weights measured with the functioning load cell, were used for the value of $W$ in Equation (1). The factors were determined by referring to the bi-monthly measured data of sediment discharge.

An electrically controlled drainage valve at the bottom of the container opens for automatic drainage of water from the container in order to continue the surface runoff observation even during continuous rainfall events. A tipping bucket type rain gauge ( $1 \mathrm{~mm}$ per a tipping) was placed to beside the observation slope. If no rainfall was observed by the rain gauge for a period of $60 \mathrm{~min}$, and at the same time, if the water level was higher than the height of $15 \mathrm{~cm}$ above the highest level of the surface of sediment in the container at the time, then the water in the container would be automatically drained down to a predetermined water level to prevent the container from filling with surface runoff. The drainage automatically stops if water level lowers to the above-mentioned height. The highest level of the surface of sediment was determined on the basis of calculation under an assumption that the sediment deposits flatly assuming that the grain density was $2.703 \mathrm{~g} / \mathrm{cm}^{3}$ and the sediment concentration was $1.5 \mathrm{~g} / \mathrm{cm}^{3}$.

\section{ASH FALL, RAINFALL AND OCCURRENCE OF DEBRIS FLOWS}

\subsection{Volcanic eruption and amount of ash fall}

Figure 5 shows the number of eruptions of Sakurajima Volcano during the period from February 2012 to December 2012. The number of eruptions per day is drawn with a broken line, and the number of eruptions where the ash cloud flowed southeast, namely in the direction of the Arimura River basin, is drawn with a red solid line.

The grain size distribution of ash falling during the observation period is shown by the solid line in Figure 6. The grain density of the volcanic ash 
collected during the observation period by an ash-receiving tray with a receiving area of about 750 $\mathrm{cm}^{2}$ that was placed beside the observation slope was $2.699-2.752 \mathrm{~g} / \mathrm{cm}^{3}$. The grain density of sediment accumulated in the container was found to be $2.689-2.729 \mathrm{~g} / \mathrm{cm}^{3}$.

The amount of ash fall was monitored using an Automatic Tephra and Rain gauge (ATR gauge) installed near the observation slope. ATR gauge is equipment that enables automatic and continuous measurement of the amount of tephra fall and the amount of rainfall. [Kisa et al., 2011] shows the details and the results of the verification of the ATR gauge, therefore the outline of the ATR gauge is described here. ATR gauge equips a container to collect ash fall and rainfall with $200 \mathrm{~mm}$ in diameter and $300 \mathrm{~mm}$ in height. The ATR gauge equipped with a load cell installed under the container is used to measure the weight of ash fall and rainfall. In fact, the principal of measurement is same as the surface runoff measurement. Amount of ash fall are estimated by Equation (1), where $W_{s}$ is rearranged to the weight of ash fall deposit in the container, $\rho_{s}$ is the grain density of ash taken as $2.64 \mathrm{~g} / \mathrm{cm}^{3}$ and $S$ is $314 \mathrm{~cm}^{2}$. The water level in the ATR gauge should be kept higher than the highest level of the surface of ash deposit to produces amount of ash fall accurately using Equation (1).

The amount of ash fall in Figure 5 is cumulative value which was collected by the ATR gauge. In this case, the amount of ash fall was recorded at intervals of an hour and the average values of each 12 hours are shown in Figure 5. Although the resolution of the amount of ash fall is approximately $\pm 0.5 \mathrm{~kg} / \mathrm{m}^{2}$, the value measured by the ATR gauge sometimes decreased after it increased more than the resolution. The reason is assumed that the water level in the ATR gauge was sometimes lower than the highest level of the surface of ash deposit due to the daily evaporation during less rainfall period, and ash fall amount is measured in surplus temporally. The estimated values during the periods that the amount of ash fall assumed to be measured in surplus are described in Figure 5 with the broken lines.

The amount of ash fall varied periodically according to the number of eruptions and the seasonal wind direction. Approximately $27 \mathrm{~kg} / \mathrm{m}^{2}$ of ash fall was observed during period $<\mathrm{A}>$, from mid-March to mid-May 2012; and $1 \mathrm{~kg} / \mathrm{m}^{2}$ of ash fall was observed in period $<\mathrm{B}>$, from late in May to late in September 2012. This could be converted into approximately $0.39 \mathrm{~kg} / \mathrm{m}^{2} / \mathrm{day}$ and $0.01 \mathrm{~kg} / \mathrm{m}^{2} /$ day, respectively. In this paper, the period $\angle \mathrm{A}>$ is defined as the periods with relatively

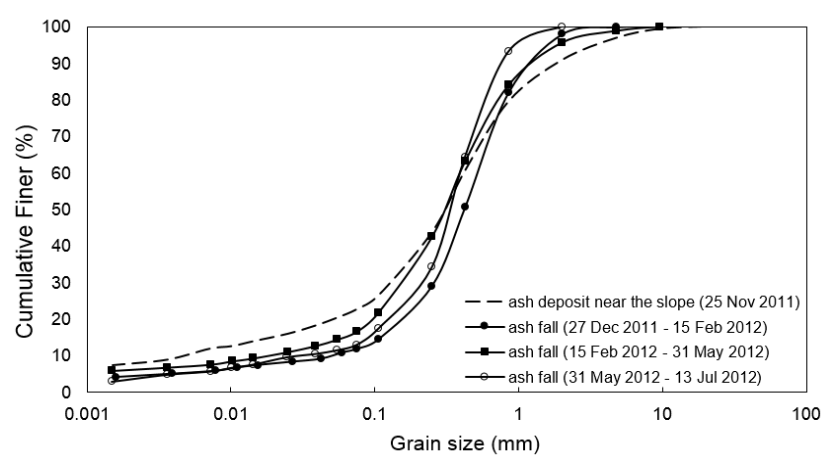

Fig. 6 The grain size distributions of ash fall

high daily ash fall rate and the period $<\mathrm{B}>$ is defined as the periods with relatively low daily ash fall rate. If the volumetric density of the layer of the ash fall deposit is assumed to be $1.5 \mathrm{~g} / \mathrm{cm}^{3}$, the volcanic ash thickness during period $<\mathrm{A}>$ was about $1.8 \mathrm{~cm}$.

\subsection{Observed rainfall}

The rain gauge placed beside the observation slope was an ordinary tipping type rain gauge. The amount of rainfall sometimes could not be measured accurately or immeasurable, especially during the period of relatively high ash fall rate; because the ash could clog the intake hole of the rainfall gauge or it could accumulate on the some part of the tipping bucket. So, we used a telemetric rain gauge located $900 \mathrm{~m}$ southeast of the observation slope to make decisions rainfall events because it was tephra fall resistant type.

In cases when the telemetric rain gauge at the Arimura River does not detect rainfall for $60 \mathrm{~min}$ after the cessation of rainfall, the rainfall event is defined as complete. Figure 7 shows total rainfall amount of each rainfall event. There were 197 rainfall events from mid-February to mid-September 2012.

\subsection{Debris flow occurrences}

In the observation period, 9 debris flows were reported to occur in the Arimura River in 2012; March $23^{\text {rd }}$, April $3^{\text {rd }}$, April $11^{\text {th }}$, June $15^{\text {th }}$, June $21^{\text {st }}$, July $7^{\text {th }}$, July $12^{\text {th }}$, August $1^{\text {st }}$ and August $23^{\text {rd }}$. A wire sensor is located on the crest of Arimura No. 1 check dam which is approximately $500 \mathrm{~m}$ downstream side from the observation site. The definition of occurrences of debris flow is the time when the wire sensor set with the height of $60 \mathrm{~cm}$ detects. In Figure 7, the occurrences of debris flow are marked with vertical broken lines. Figure 8 shows an example photo of debris flow which occurred in the Arimura River on $21^{\text {st }}$ June, 2012. 


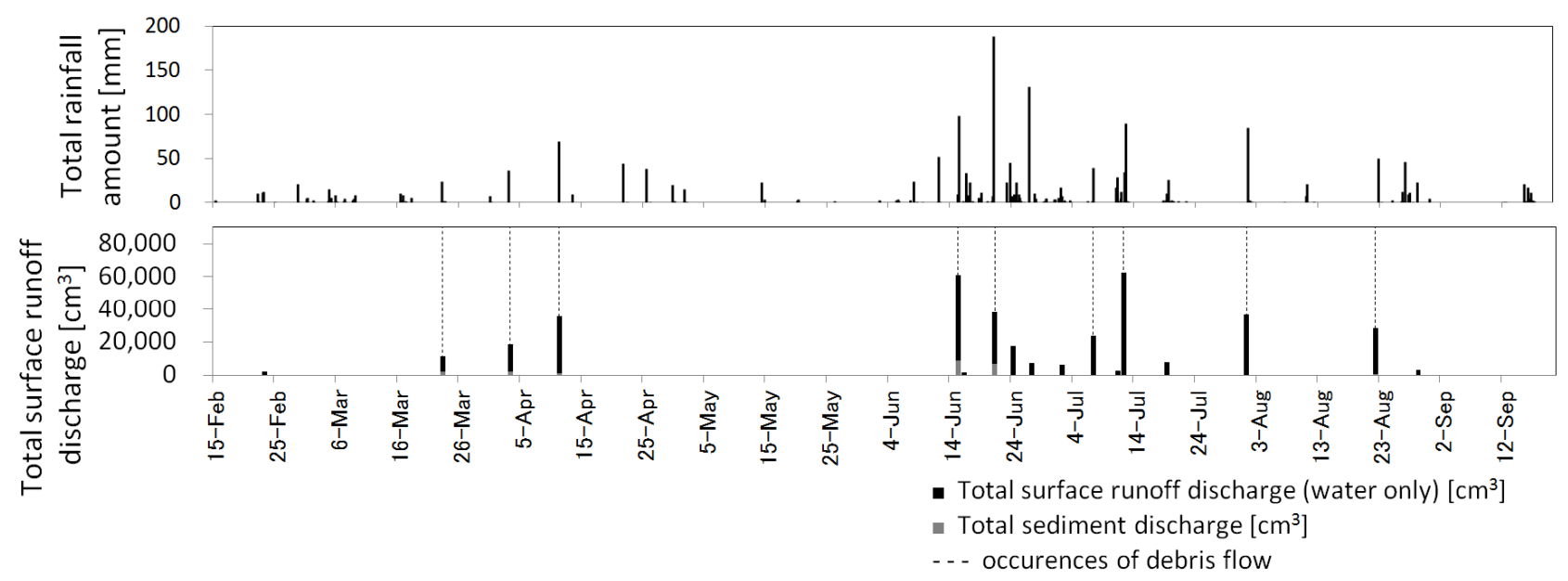

Fig. 7 Total rainfall amount and Total surface runoff discharge

\section{RESULT OF SURFACE RUNOFF OBSERVATIONS}

An occurrence of surface runoff is defined as an increase in the water level by $1 \mathrm{~mm}$ in the container that receives surface runoff or more. There were 23 rainfall events accompanied by the occurrence of surface runoff.

Figure 7 shows the total amount of surface runoff discharge observed. Table 1 lists the observation results of rainfall events accompanied by the occurrence of surface runoff. The rain data showed in the Table 1 was listed either the data of the telemetric rain gauge or the data of the rain gauge placed beside the observation slope. The data of the rain gauge beside the observation slope was used in the case it was assumed to have not been abnormal while referring the conditions of the measurement at the time of cleaning up for maintenance and comparing with the data of the telemetric rain gauge. Figure 9 shows hydrographs (total volume of water and sediment) of representative instances of the observation results that include the period with relatively high daily ash fall rates and the period with relatively low daily ash fall rates. The vertical broken line means the time when debris flow occurred.

\section{DISCUSSION ON SHORT-TERM ASH FALL AND RAINFALL THRESHOLD FOR DEBRIS FLOW OCCURRENCE}

5.1 Relationship between the occurrence of surface runoff on the slope and the occurrence of debris flows

According to the Figure 7, it is shown that the occurrence of debris flows was always accompanied by surface runoff. When a rainfall event was

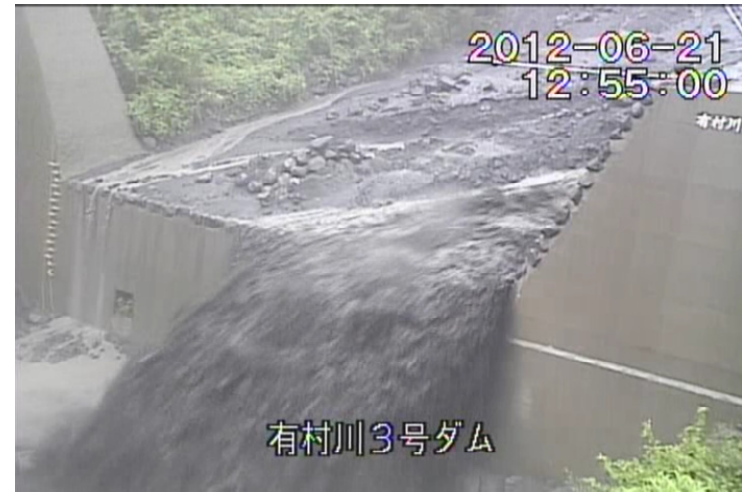

Fig. 8 An example of debris flow which occurred in the Arimura River on $21^{\text {st }}$ June, 2012

accompanied by debris flow, it is also shown that the total amount of surface runoff events was relatively large. As shown in the previous work [Jitousono et al., 1991], therefore, it is assumed that the occurrence of surface runoff on slopes in the basin is one of the major causes of the occurrence of debris flows in the Arimura River. Hereafter in this paper, the rainfall conditions occurring during times of surface runoff will be considered.

\subsection{Rainfall intensity during periods of surface runoff}

The difference in amounts of short-term ash fall during the observation period and the differences in the intensity of rainfall inducing surface runoff on the slope were studied. In Figure 10, every 10-minute rainfall event occurring at the time of onset of surface runoff events is marked with small open circles. When surface runoff occurs several times during a rainfall event, the 10-minute rainfall at the time of every re-occurrence is also indicated. For rainfall events that are not accompanied by surface runoff, the maximum 10-minute rainfall during the rainfall event is marked with " $x$ ". 
Table 1 Rainfall factors and observation results of rainfall events accompanied by the occurrence of surface runoff

\begin{tabular}{|c|c|c|c|c|c|c|c|c|c|c|c|c|c|c|c|c|}
\hline \multirow{2}{*}{ No. } & \multirow{2}{*}{$\begin{array}{l}\text { Starting time of } \\
\text { rainfall event }\end{array}$} & \multirow{2}{*}{$\begin{array}{l}\text { Finish time of } \\
\text { rainfall event }\end{array}$} & \multirow{2}{*}{$\begin{array}{l}\text { Maximum 10- } \\
\text { minute } \\
\text { rainfall } \\
{[\mathrm{mm} / 10 \mathrm{~min}]}\end{array}$} & \multirow{2}{*}{$\begin{array}{c}\text { Rainfall } \\
\text { amount [mm] }\end{array}$} & \multirow{2}{*}{$\begin{array}{l}\text { Maximum 10- } \\
\text { minute } \\
\text { surface } \\
\text { runoff } \\
{\left[\mathrm{cm}^{3} / 10 \mathrm{~min}\right]}\end{array}$} & \multirow{2}{*}{$\begin{array}{l}\text { Amount of } \\
\text { surface } \\
\text { runoff }\left[\mathrm{cm}^{3}\right]\end{array}$} & \multirow{2}{*}{$\begin{array}{c}\text { Amount of } \\
\text { sediment } \\
\text { discharge } \\
{[\mathrm{g}]}\end{array}$} & \multicolumn{5}{|c|}{$\begin{array}{l}\text { 10-minute rainfall of the surface } \\
\text { runoff occrences }[\mathrm{mm} / 10 \mathrm{~min}]\end{array}$} & \multirow{2}{*}{$\begin{array}{l}\text { The time of } \\
\text { occurrence of first } \\
\text { - surface runoff }\end{array}$} & \multirow{2}{*}{$\begin{array}{l}\text { Rainfall } \\
\text { amount } \\
\text { preceding } \\
\text { occurrence of } \\
\text { surface runoff } \\
\quad[\mathrm{mm}]\end{array}$} & \multirow{2}{*}{$\begin{array}{l}60-\text { minute } \\
\text { rainfall amount } \\
\text { preceding } \\
\text { occurrence of } \\
\text { surface runoff } \\
{[\mathrm{mm} / 60 \mathrm{~min}]}\end{array}$} & \multirow{2}{*}{$\begin{array}{l}\text { Period of no } \\
\text { rain days of } \\
\text { preceding the } \\
\text { surface runoff } \\
\text { occurrence } \\
\text { [day] }\end{array}$} \\
\hline & & & & & & & & 1st & 2nd & $3 r d$ & 4th & 5th & & & & \\
\hline 1 & 23-Feb 6:20 & 23-Feb 6:50 & 5 & 12 & 630 & 1,220 & 0 & 5 & - & - & - & - & $23-F e b 6: 40$ & 6 & 6 & 0.08 \\
\hline 2 & 23-Mar 8:00 & 23-Mar 9:50 & 4 & 24 & 7,941 & 10,925 & 8,633 & 4 & - & - & - & - & $23-\operatorname{Mar} 9: 10$ & 12 & 11 & 4.89 \\
\hline 3 & 3-Apr 5:00 & 3-Apr 8:30 & 7 & 37 & 5,916 & 17,956 & 7,397 & 7 & 4 & - & - & - & 3-Apr 6:40 & 14 & 10 & 2.88 \\
\hline 4 & 11-Apr 8:30 & 11-Apr 12:40 & 7 & 69 & 6,817 & 35,187 & 5,486 & 8 & 4 & 6 & - & - & 11-Apr 10:10 & 21 & 11 & 8.00 \\
\hline 5 & 15-Jun 11:30 & 15-Jun 21:40 & 14 & 99 & 32,748 & 60,427 & 24,291 & 14 & 4 & 8 & - & - & 15-Jun 18:20 & 17 & 5 & 0.05 \\
\hline 6 & 16-Jun 16:00 & 16-Jun 21:30 & 4 & 34 & 928 & 1,043 & 0 & 4 & - & - & - & - & 16-Jun 20:20 & 25 & 6 & 0.35 \\
\hline 7 & 21-Jun 2:50 & 21-Jun 19:00 & 10 & 189 & 10,526 & 37,768 & 0 & 6 & 7 & 5 & 4 & 4 & $21-J u n 8: 20$ & 44 & 11 & 0.06 \\
\hline 8 & 23-Jun 19:50 & 24-Jun 4:40 & 4 & 45 & 581 & 1,104 & 0 & 4 & 3 & - & - & - & 24-Jun 1:40 & 32 & 7 & 0.08 \\
\hline 9 & 24-Jun 5:50 & 24-Jun 6:20 & 3 & 7 & 411 & 625 & 0 & 3 & - & - & - & - & 24-Jun 6:00 & 3 & 3 & 0.05 \\
\hline 10 & 24-Jun 11:00 & 24-Jun 11:10 & 3 & 6 & 1,807 & 2,264 & 0 & 4 & 3 & - & - & - & 24-Jun 11:10 & 3 & 3 & 0.06 \\
\hline 11 & 24-Jun 13:00 & 24-Jun 14:40 & 4 & 9 & 341 & 1,016 & 0 & 4 & - & - & - & - & 24-Jun 13:10 & 3 & 3 & 0.08 \\
\hline 12 & 24-Jun 20:50 & 24-Jun 22:20 & 12 & 23 & 9,009 & 16,845 & 2,983 & 11 & - & - & - & - & 24-Jun 21:20 & 7 & 7 & 0.13 \\
\hline 13 & 26-Jun 23:00 & 27-Jun 17:50 & 5 & 131 & 1,379 & 6,553 & 0 & 4 & - & - & - & - & 27-Jun 8:00 & 37 & 7 & 0.80 \\
\hline 14 & 2-Jul 2:30 & 2-Jul 3:00 & 9 & 17 & 4,207 & 5,675 & 1,298 & 8 & - & - & - & - & 2-Jul 2:40 & 2 & 2 & 0.05 \\
\hline 15 & 7-Jul 10:10 & 7-Jul 12:10 & 10 & 39 & 11,348 & 22,935 & 0 & 5 & 5 & - & - & - & 7-Jul 10:20 & 3 & 3 & 0.10 \\
\hline 16 & 11-Jul 8:00 & 11-Jul 12:00 & 5 & 29 & 1,118 & 1,872 & 0 & 4 & - & - & - & - & 11-Jul 11:40 & 22 & 1 & 0.14 \\
\hline 17 & 11-Jul 20:20 & 11-Jul 21:40 & 2 & 5 & 1,338 & 1,780 & 0 & 2 & - & - & - & - & 11-Jul 21:20 & 2 & 2 & 0.23 \\
\hline 18 & 12-Jul 11:20 & 12-Jul 14:30 & 8 & 35 & 10,317 & 16,557 & 0 & 3 & - & - & - & - & 12-Jul 12:30 & 8 & 7 & 0.05 \\
\hline 19 & 12-Jul 16:40 & 12-Jul 21:00 & 10 & 90 & 11,896 & 61,809 & 0 & 10 & 6 & 7 & - & - & 12-Jul 12:30 & 40 & 7 & 0.09 \\
\hline 20 & 19-Jul 14:50 & 19-Jul 18:10 & 7 & 26 & 2,664 & 7,255 & 571 & 8 & - & - & - & - & 19-Jul 15:50 & 3 & 3 & 0.19 \\
\hline 21 & 1-Aug 12:40 & 1-Aug 20:10 & 14 & 85 & 15,484 & 36,166 & 1,145 & 5 & - & - & - & - & 1-Aug 19:00 & 42 & 15 & 9.98 \\
\hline 22 & 22-Aug 19:40 & 23-Aug 3:40 & 14 & 50 & 18,105 & 27,554 & 4,394 & 4 & 6 & - & - & - & 22-Aug 21:50 & 14 & 12 & 10.47 \\
\hline 23 & 29-Aug 4:00 & 29-Aug 8:20 & 7 & 23 & 2,154 & 2,489 & 0 & 7 & - & - & - & - & 29-Aug 4:10 & 7 & 7 & 0.67 \\
\hline
\end{tabular}

*hatching means the rainfall events which debris flow occurred
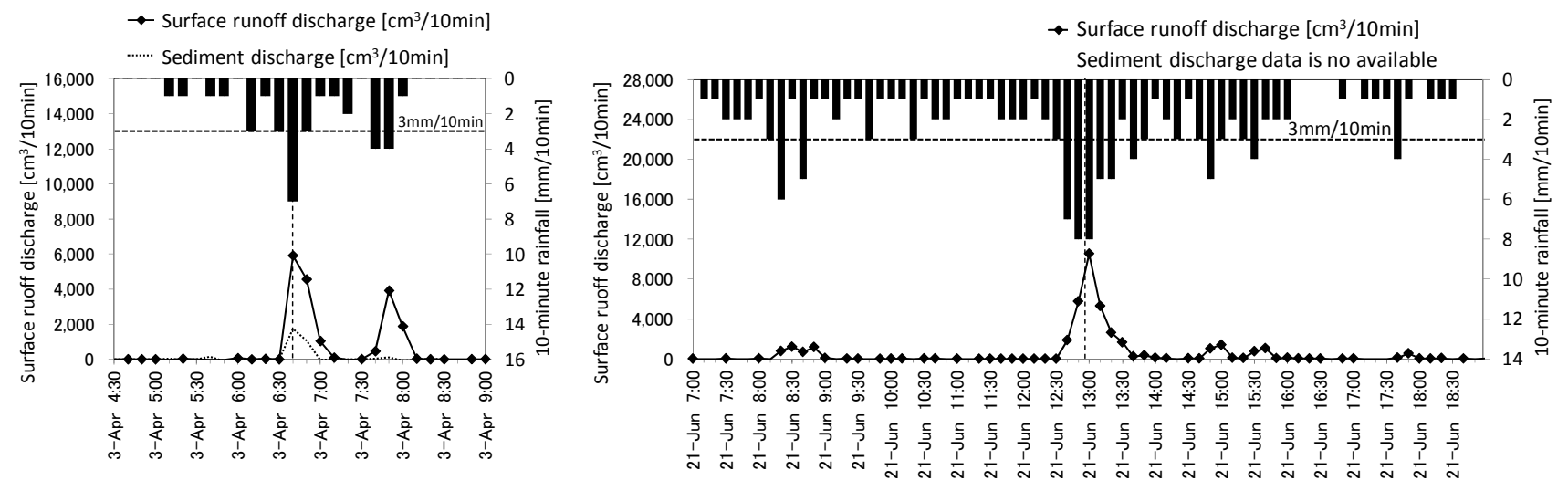

Fig. 9 Examples of hydrograph from the observation slope

* The vertical broken line means the time debris flow was detected by the wire sensor

In period $\angle \mathrm{A}\rangle$, the period with relatively high daily ash fall rate, rainfall events where the maximum 10-minute rainfall was $3 \mathrm{~mm}$ or less were not accompanied by surface runoff. Surface runoff only occurred when the 10-minute rainfall of a rainfall event produced $4 \mathrm{~mm}$ or more. On the other hand, during period $<\mathrm{B}>$, the period with a relatively low daily ash fall rate, rainfall events where the maximum 10-minute rainfall was $3 \mathrm{~mm}$ or less were not accompanied by surface runoff, with the exception of some rainfall events. In addition, surface runoff occurred when the 10-minute rainfall of a rainfall event was $4 \mathrm{~mm}$ or more in most of the rainfall events. For the short-term variance of ash fall observed during the observation period, no obvious difference was observed in rainfall intensity at the time of the onset of surface runoff between periods $<\mathrm{A}>$ and $<\mathrm{B}>$. 10-minute rainfall at the time of the onset of surface runoff events $x$ the maximum 10-minute rainfall of no surface runoff event

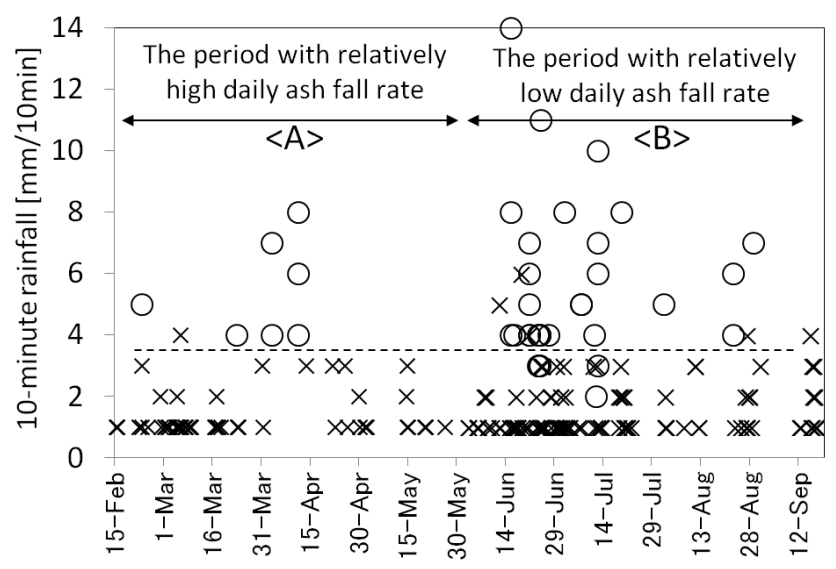

Fig. 10 Rainfall intensity of onset of surface runoff and the maximum rainfall intensity of rainfall with no surface runoff 
5.3 Apparent infiltration capacity of the slope during the period of occurrence of surface runoff

In Section 5.1, the authors showed that debris flows occurred when surface runoff was relatively large in scale. To investigate the influence of a difference on conditions of surface runoff occurrence between period $\langle\mathrm{A}\rangle$ and $\langle\mathrm{B}\rangle$, the authors compared the apparent infiltration capacity of the slope during of the period of occurrence of surface runoff.

The apparent infiltration capacity is calculated from Equation (2) as follows:

$$
\begin{aligned}
& I=\left(Q_{r}-Q_{f}\right) \cdot 10 /\left(A^{\prime} \cdot T\right) \\
& Q_{r}=R_{t} \cdot A / 10 \\
& Q_{f}=Q_{t}-Q_{s} \\
& A^{\prime}=A-a
\end{aligned}
$$

where $I$ is the apparent infiltration capacity of the slope ( $\mathrm{mm} / \mathrm{hr}), Q_{r}$ is the total amount of rainfall on the slope during of the period of occurrence of surface runoff $\left(\mathrm{cm}^{3}\right), Q_{f}$ is the total amount of surface runoff during of the period of occurrence of surface runoff (water only) $\left(\mathrm{cm}^{3}\right), A^{\prime}$ is the area of the observation slope with the exception of the impermeable area $\left(\mathrm{cm}^{2}\right), T$ is the period of occurrence of surface runoff $(\mathrm{hr}), R_{t}$ is the total amount of rainfall during the period of occurrence of surface runoff $(\mathrm{mm}), A$ is the area of the observation slope $\left(\mathrm{cm}^{2}\right), Q_{t}$ is the total amount of surface runoff (water and sediment) $\left(\mathrm{cm}^{3}\right)$, and $a$ is the impermeable area the pavement of rock blocks $\left(\mathrm{cm}^{2}\right)$.

Figure 11 shows the calculated values of the apparent infiltration capacity of the slope of the rainfall events which caused debris flow. We compared the lower limits of the apparent infiltration capacity of the slope between the period $<\mathrm{A}>$ and $\angle \mathrm{B}>$. The lower limits of the apparent infiltration capacity of the slope during the period $<\mathrm{A}>$ ranged between about $11 \mathrm{~mm} / \mathrm{hr}$ and $14 \mathrm{~mm} / \mathrm{hr}$ and those during period $<\mathrm{B}>$ ranged between about $15 \mathrm{~mm} / \mathrm{hr}$ and $25 \mathrm{~mm} / \mathrm{hr}$. It is seemed that the apparent infiltration capacity slightly increased and varied, despite the fact that no difference was observed in the intensity of the 10-minute rainfalls inducing surface runoff (as mentioned in Section 5.2). The authors hypothesize that the reasons for this are as follows. As illustrated in Figure 12, rills were remarkably formed on the slope by surface erosion during the observation period. In period $<\mathrm{A}\rangle$, the surface of the rills was covered with volcanic ash being fed continuously. However, in

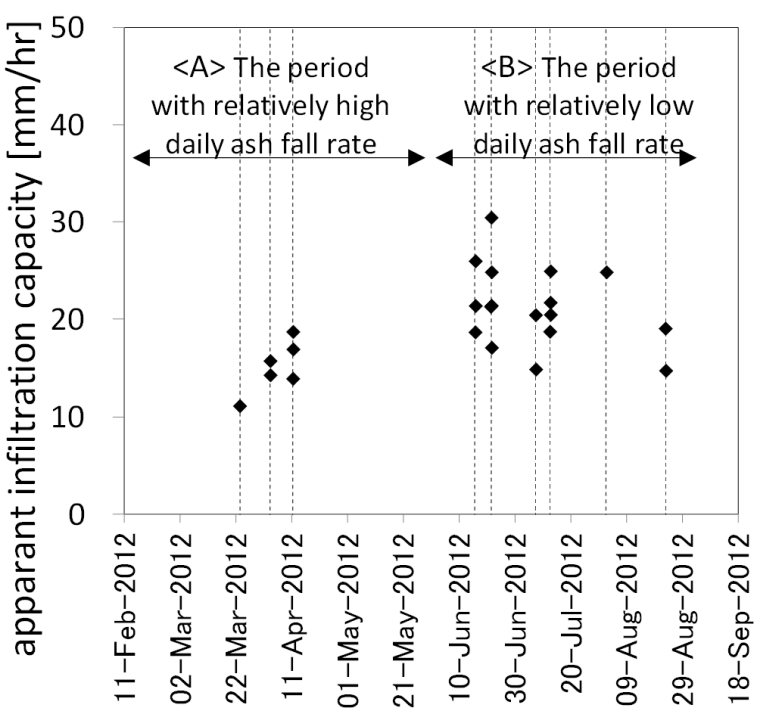

Fig. 11 Apparent infiltration capacity of the observation slope
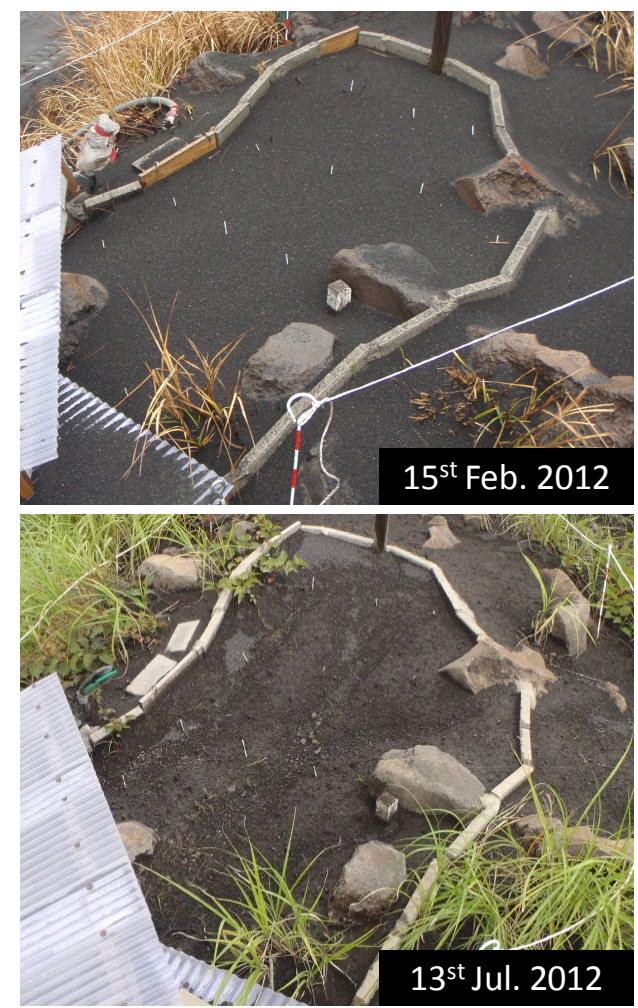

Fig. 12 The observation slope in period $<\mathrm{A}>$ (upper) and in period $<$ B $>$ (lower)

period $<\mathrm{B}>$, since there were more frequent rainfalls and less ash fall, rills formed by erosion due to surface runoff were not covered with volcanic ash and were exposed at the surface. Assuming that infiltration capacity of rills is relatively high compared with that of interrill surface, the infiltration capacity of the whole observation slope apparently increased. If the assumption is made that surface runoff occurs on interrills, an explanation can be given for the slightly differing apparent 
infiltration capacity of the slope, in spite of the lack of variation in rainfall intensity at the time of the onset of surface runoff.

\subsection{Rainfall loss from the onset of rain to the occurrence of surface runoff}

The threshold intensity of rainfall that induces surface runoff was $3-4 \mathrm{~mm} / 10 \mathrm{~min}$, as shown in Section 5.2. However, at the onset of rainfall, there were times when surface runoff did not occur, despite a rainfall intensity of $4 \mathrm{~mm} / 10 \mathrm{~min}$ or more. There is rainfall loss from the onset of rain to the occurrence of surface runoff on the slope. It is considered to be an important rainfall indicator for the prediction of the time of occurrence of debris flows.

The previous work reported surface runoff on forest slopes covered with volcanic ash and pointed out that when the observation slopes had been wet by previous recent rain, surface runoff occurred even when there was weak rainfall intensity, compared with the case where it had not rained previously [Jitousono et al., 1989].

Rainfall loss from the onset of rain to the occurrence of surface runoff is shown in Table 1. Loss of rainfall from the beginning of rain is influenced by the rainfall pattern and becomes large when there is continuation of weak rainfall intensity. To compare the rainfall loss from the onset of rain to the occurrence of surface runoff, 60-minute rainfall amount just before the occurrence of surface runoff is summarized in Table 1. According to this table, 60-minute rainfall amount preceding the occurrence of surface runoff ranges between 6 and $11 \mathrm{~mm} / 60 \mathrm{~min}$, in period $<\mathrm{A}>$, and between 1 and 15 $\mathrm{mm} / 60 \mathrm{~min}$ in period $\angle \mathrm{B}>$. The lower limit of period $<\mathrm{B}>$ is found to be lower than that of period $<\mathrm{A}>$. However, this may be because it had rained frequently during period $<\mathrm{B}>$; and therefore, there were some cases where the surface of the slope had already been wet before the rainfall event. In this paper, a no-rain period is used as an indicator for the degree of wetness of the surface.

The relationship between no-rain periods and the preceding 60-minute rainfall just before the occurrence of surface runoff in rainfall events is shown in Figure 13. The small open circle indicates the preceding 60-minute rainfall just before the occurrence of surface runoff in rainfall events that are accompanied by surface runoff. It should be noted that the time of occurrence of only the first event of surface runoff was used for rainfall events that were accompanied with several events of surface runoff.

When the no-rain period lasted more than 3 days,

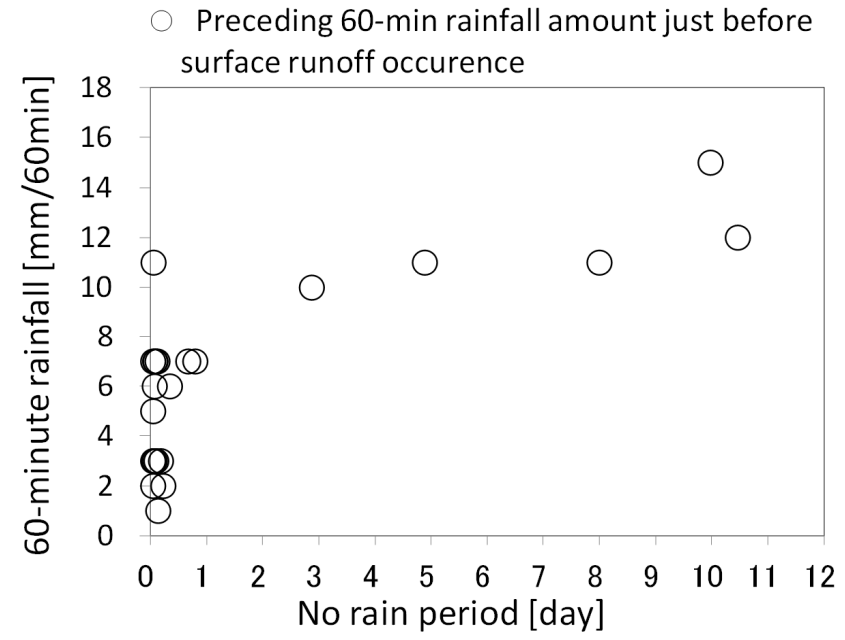

Fig. 13 Preceding 60-minute rainfall amount just before the occurrence of surface runoff

the amount of the preceding 60 -minute rainfall just before the occurrence of surface runoff measured $10-15 \mathrm{~mm} / 60 \mathrm{~min}$ while when the no-rain period is shorter than one day smaller amount of the preceding 60-minute rainfall can trigger surface runoff. This result shows that surface runoff can occur with smaller rainfall loss in the case of no-rain periods shorter than one day and the surface of the slope is relatively wet while surface runoff doesn't occur with rainfall loss less than $10 \mathrm{~mm}$ in the case of no-rain periods longer than three days.

\section{CONCLUSIONS AND FUTURE CHALLENGES}

This paper discusses the conditions involved for the occurrence of surface runoff at an observation site at Sakurajima where volcanic ash is constantly falling. The observation result suggests that one of major cause of the occurrence of debris flows in the Arimura River is due to the occurrence of surface runoff on the slopes of the basin. Compared periods with relatively high daily ash fall rates and periods with relatively low daily ash fall rates, the amount of ash fall observed in this study, did not cause an obvious difference in the intensity of rainfall that induces surface runoff. Similarly, no perceptible difference was observed in the apparent infiltration capacity of the slope. As far as loss of rainfall from the beginning of rain is concerned, when there is a lengthy no-rain period there is an increase in the amount of rainfall preceding the occurrence of surface runoff, although the influence of short-term ash fall has not been fully considered.

These are the preliminary results at the time when the authors obtained the data included in each period with relatively high ash fall rate and 
relatively low ash fall rate. The observation period of this study was shorter than a year. It is necessary to continue the observation to obtain more data. To elucidate the influence of an increase in short-term ash fall and the changes of physical properties in pyroclastic fall materials on conditions for the occurrence of surface runoff is a future challenge.

ACKNOWLEDGMENT: The authors would like to thank the Ohsumi Office of the River and National Highways, Kyushu Regional Development Bureau, Ministry of Land, Infrastructure, Transport and Tourism. In for providing us with the slope for our study and for information on the occurrence of debris flows, rainfall data obtained from the telemetric rain gauge and the ash fall data obtained from the ATR gauge. The authors are also grateful to the Japan Meteorological Agency for the data on eruptions of Sakurajima Volcano.

\section{REFERENCES}

Collins, B.D. and Dunne, T. (1986): Erosion of tephra from the 1980 eruption of Mount St. Helens, Geological Society of America Bulletin, v.97, pp. 896-905.

Ikeya, H. (1993): The Mecahnism on the Occurrence of Debris Flows in the Mizunashi River, Unzen Volcano, Journal of the Japan Society of Erosion Control Engineering, Vol. 47, No. 2, pp. 15-21 (in Japanese).

Jitousono, T. and Shimokawa, E. (1989): Surface Runoff on Tephra-Covered Hillslope in Sakurajima Volcano, Journal of the Japan Society of Erosion Control Engineering, Vol. 42, No. 3, pp. 18-23 (in Japanese).

Jitousono, T. and Shimokawa, E. (1991): Effects of Volcanic Activity on Occurrence and Runoff of Debris Flow in
Sakurajima Volcano, Journal of the Japan Society of Erosion Control Engineering, Vol. 43, No. 6, pp. 9-15 (in Japanese with English Abstract).

Kisa, H., Yamakoshi, T., Ishizuka, T., Fukuda, K., Shimomura, S., Ohara, D. and Tajima, Y. (2011): Continuous monitoring of volcanic ash falls using Kohai-hyeto meter for Sakurajima Volcano, Seminar Nasional Penanganan Aliran Sedimen dan Dies Natalis X Proguram Pendidikan Bencana di Magister Peengelolaan Bencana Alam Fakultus Teknik UGM, pp.89-93

Nishida, K., Kobashi, S. and Mizuyama T. (1998): How Has Revegetation Changed Surface Runoff and Sediment Discharge on Pyroclastic Sediments in Unzen Volcano?, The Japanese Society of Revegetation Technology, Vol. 23, No. 4, pp. 249-255 (in Japanese with English Summary).

Ohsumi Development Office, Kyushu Regional Development Bureau, Ministry of Construction (1988): Sakurajima no dosekiryu (in Japanese) [Reports on debris flow in Sakurajima]

Ohsumi Office of River and National Highway, Kyushu Regional Development Breau, Ministry of Land, Infrastructure, Transport and Tourism (2007): Sakurajima kazan sabo chousakenkyu seikashu (in Japanese) [Sakurajima Volcano Sabo Survey and Research Results], pp. 79-87.

Yamakoshi, T., Mizuyama, T., Uchida, T., Nomura, Y., Anyoji, N. and Hashinoki, T. (2002): Temporal change in infiltration capacity and sediment discharge of the tephra-covered slope of Miyakejima Volcano in the first post-eruption year, Journal of the Japan Society of Erosion Control Engineering, Vol. 55, No. 2, pp. 36-42 (in Japanese with English Abstract).

Received: 20 August, 2013

Accepted: 12 May, 2014 